\title{
Understanding the organizational critical activities of manufacturers in case studies
}

\author{
Wei-Hsi Hung ${ }^{1, *}$, Tsung-Yueh $\mathrm{Lu}^{2}$, Mei-Fang $\mathrm{Wu}^{2}$, and Yun-Chen $\mathrm{Lin}^{3}$ \\ ${ }^{1}$ Department of Management Information Systems, National Chengchi University, No.64, Sec.2, \\ ZhiNan Rd., Wenshan District, Taipei City 11605, Taiwan, R.O.C. \\ ${ }^{2}$ Department of Industrial Engineering \& Systems Management, Feng Chia University, 100 Wenhwa \\ Road, Taichung 40724, Taiwan, R.O.C. \\ ${ }^{3}$ Department of Information Management, National Chung Cheng University, 168 University Road, \\ Min-Hsiung, Chia-Yi 62102, Taiwan, R.O.C.
}

\begin{abstract}
Manufacturers tend to carry out certain important and continuous activities with respect to internal operations which could contribute to their success. These activities are termed organization critical activities (OCAs). The main objective of this study is to elicit the OCAs in the manufacturing industry to understand what can cause them to be successful. Through the case study approach including the interviews with the senior managers from three manufacturing companies in Taiwan and a series of prioritizing activities, 12 OCAs have been identified. This study found that Taiwanese manufacturers placed more importance on the activities of quality and cost control while placed relatively less importance on the marketing related activities. More findings and future research suggestions are also provided.
\end{abstract}

\section{Introduction}

Manufacturers tend to carry out certain important and continuous activities with respect to internal operations which could contribute to their success. These activities, are termed organization critical activities [4], being granted significant resources and supervision from the senior management. Organization Critical Activities (OCAs) was introduced by Hung [4], and is defined as: the activities constantly conducted by the organization for the success in the industry. They are regarded as an essential to the short-term, mid-term, and long-term success of the organization. Thus they receive a huge amount of resources and frequent supervised and directed by the senior management.

However, there is the lack of research studying what organization critical activities are conducted by manufacturers in order to ensure their success. The main objective of this study is to elicit the OCAs in the manufacturing industry to understand what can cause them to be successful.

${ }^{*}$ Corresponding author: fhung@nccu.edu.tw 


\section{Organization critical activities}

Activities are the implementations of works within the organization [10]. They are established in strategies, tactics, and various organizational levels $[5,6,8]$. Activities are to be implemented during works, and they are the minimum unit of work in the organization which will support the works of different departments and levels. Different departments and levels will support different activities, yet they will all result in the same result, which is the enhancement of performance and efficiency of work due to support by activities.

It was defined in research of Hung [4] that organization critical activities are the activities to be constantly implemented by an organization for success of industry. Organization Critical Activities (OCA) are regarded as an essential element for the shortterm, mid-term, and long-term success of industry. Thus they will receive a huge amount of resources and frequent supervision and instruction from high level management.

Hung [4] summarized the definitions of process flow by various scholars [1, 2, 3, 7, 11, $12]$, and proposed that processes are mutually correlated activities among various levels. This kind of activity is embedded in a set of rules and resources. It can enforce and grant social activities as shown in Table 1 below.

Table 1. The inclusion relation among process flow, task, activity, and OCA [4].

\begin{tabular}{|c|c|c|}
\hline Name & Content & Range \\
\hline Process & Activity, entity, rule, resource & $1 \cdot 2 \cdot 3 \cdot 4$ \\
\hline Task & Resource and activity & $2 \cdot 3 \cdot 4$ \\
\hline Activity & Critical and non-critical & $3 \cdot 4$ \\
\hline OCA & Critical activity for business success & 4 \\
\hline
\end{tabular}

The comparison of activity, task, and process involving OCA is as shown in the figure above. The activity is an essential core of a given process of task. An activity contains less processes and tasks. Organization critical activity is the activity constantly carried out by organization for achieving success, which must be greatly supported by high level supervisors with a great deal of resources. They are the activities to be constantly carried out by an organization for achieving success. They are the activities and essential element for an industry to achieve short-term, mid-term, and long-term success. It is only focused on whether or not the activity itself can achieve the organizational success.

In project management, critical path is a method for determining the starting and ending date of a project. The result of this method is to find a critical path, or to form a shortest chain of activities from start to finish. The critical path of activities is called critical activities [9], and the project management process flow can contribute to identification of task items of critical activities. Even though the term of "Critical Activities" in project management is very similar to the term of "Organization Critical Activities", critical activities actually refer to the short-term timeframe dedicated to completing a given task in project management, rather than a long-term activity for organizational success. 


\section{Methodology}

In this study we use the manufacturing industry in Taiwan as an example to investigate what OCAs are conducting in order to ensure manufacturing companies' success. The data collection and analysis methods were case study and thematic coding. A total of 15 supervisors from 14 domestic manufacturing companies were participated in the interviews, and all interviews were voice recorded and analyzed. The basic company information, company background, and personal information of respondent are as shown in Table 2.

Table 2. Basic information of respondent.

\begin{tabular}{|c|c|c|c|}
\hline Respondents & $\begin{array}{c}\text { Years of } \\
\text { work }\end{array}$ & Job/Duty & Industry \\
\hline I1 & 7 & $\begin{array}{c}\text { Chief Officer of Safety, } \\
\text { Health, and } \\
\text { Environmental } \\
\text { Protection }\end{array}$ & $\begin{array}{l}\text { Electronic components } \\
\text { industry }\end{array}$ \\
\hline $\mathrm{I} 2$ & 10 & $\begin{array}{c}\text { Chief Officer of IT } \\
\text { Department }\end{array}$ & $\begin{array}{l}\text { Automobile/Motorcycle } \\
\text { parts retailers }\end{array}$ \\
\hline $\mathrm{I} 3$ & 16 & R\&D Manager & $\begin{array}{l}\text { Automobile/Motorcycle } \\
\text { parts retailers }\end{array}$ \\
\hline $\mathrm{I} 4$ & 9 & IT Chief Leader & $\begin{array}{c}\text { Storage/Transportation } \\
\text { industry }\end{array}$ \\
\hline I5 & 12 & Procurement Manager & $\begin{array}{l}\text { Machinery and hand } \\
\text { tool industry }\end{array}$ \\
\hline I6 & 13 & Business Manager & $\begin{array}{l}\text { Chemical raw material } \\
\text { manufacturing industry }\end{array}$ \\
\hline I7 & 10 & Sales Manager & $\begin{array}{l}\text { Electronic components } \\
\text { industry }\end{array}$ \\
\hline I8 & 8 & Head of Production & $\begin{array}{l}\text { Electronic components } \\
\text { industry }\end{array}$ \\
\hline I9 & 12 & Deputy R\&D Director & $\begin{array}{l}\text { Chemical raw material } \\
\text { manufacturing industry }\end{array}$ \\
\hline $\mathrm{I} 10$ & 15 & Business Manager & $\begin{array}{l}\text { Electrical machine } \\
\text { manufacturing industry }\end{array}$ \\
\hline I11 & 6 & $\begin{array}{c}\text { Chief of General Affairs } \\
\text { and Procurement }\end{array}$ & $\begin{array}{l}\text { Storage/Transportation } \\
\text { industry }\end{array}$ \\
\hline $\mathrm{I} 12$ & 8 & $\begin{array}{c}\text { Deputy Business } \\
\text { Manager }\end{array}$ & $\begin{array}{l}\text { Chemical raw material } \\
\text { manufacturing industry }\end{array}$ \\
\hline $\mathrm{I} 13$ & 9 & Sales Manager & $\begin{array}{l}\text { Chemical raw material } \\
\text { manufacturing industry }\end{array}$ \\
\hline I14 & 9.5 & Chief of Production & $\begin{array}{l}\text { Electronic components } \\
\text { industry }\end{array}$ \\
\hline $\mathrm{I} 15$ & 9.5 & Chief of Factory Affairs & $\begin{array}{l}\text { Chemical raw material } \\
\text { manufacturing industry }\end{array}$ \\
\hline
\end{tabular}

In this study, the one-on-one interview was adopted with the semi-structural interview approach. Before each interview, the research objectives were introduced to the interviewee. During the interview, the interviewer asked the respondent how his/her company defined success without providing any information related organization critical activities, and then gradually guide the interviewee to describe the content and measure of organization critical 
activities of the company. After receiving the answer, the interviewer provided the list of organization critical activities to be confirmed and corrected by the interviewee in order to update the current OCA list. After the interviews, two experts made the suggestions and corrections to ensure that we obtained the most appropriate list of OCAs in the manufacturing industry.

\section{Results and discussions}

The results of interviews at initial stage of this study have revealed a total of 12 OCAs in the manufacturing industry. The first OCA is the development of new products. The second OCA is the development of new technology. The third OCA is marketing research. The fourth OCA is the expansion of domestic and foreign customer bases. The fifth OCA is sustaining existing customers. The sixth OCA is providing specialized services. The seventh OCA is ensuring product quality. The eighth OCA is ensuring the quality of raw material. The ninth OCA is enhancing production efficiency. The tenth OCA is providing personnel training. The eleventh OCA is increasing the efficiency of internal staff. The twelfth OCA is cost control.

After eliciting a list of OCAs, we then interviewed the senior managers from the other three manufacturing companies for prioritizing the 12 OCAs. Relevant company document was also analyzed to triangulate the given priorities. Results of the priorities given by the three case companies are shown in Table 3. The average priority of each OCAs was calculated for generating the final list of OCAs for the three manufacturing companies.

Table 3. Priorities of OCAs given by the three case companies.

\begin{tabular}{|c|c|c|c|c|c|}
\hline \multirow{2}{*}{ Priority } & OCAs & \multicolumn{3}{|c|}{ Priorities Given by the Case Companies } \\
\cline { 3 - 6 } & Case A & Case B & Case C & Average \\
\hline 1 & Ensuring product quality & 1 & 4 & 4 & 3 \\
\hline 2 & $\begin{array}{c}\text { Ensuring the quality of } \\
\text { raw material }\end{array}$ & 4 & 5 & 3 & 4 \\
\hline 3 & Cost control & 2 & 8 & 5 & 5 \\
\hline 4 & $\begin{array}{c}\text { Development of new } \\
\text { product }\end{array}$ & 7 & 9 & 1 & 5.7 \\
\hline 5 & $\begin{array}{c}\text { Development of new } \\
\text { technology }\end{array}$ & 5 & 10 & 6 & 6.7 \\
\hline 7 & $\begin{array}{c}\text { Sustaining the existing } \\
\text { customers }\end{array}$ & 11 & 2 & 10 & 6.7 \\
\hline
\end{tabular}




\begin{tabular}{|c|c|c|c|c|c|}
\hline 7 & $\begin{array}{c}\text { Enhancing production } \\
\text { efficiency }\end{array}$ & 3 & 6 & 11 & 6.7 \\
\hline 9 & Marketing research & 6 & 7 & 8 & 7 \\
\hline 10 & $\begin{array}{c}\text { Expansion of domestic } \\
\text { and foreign customer } \\
\text { bases }\end{array}$ & 12 & 3 & 7 & 7.3 \\
\hline 11 & $\begin{array}{c}\text { Providing personnel } \\
\text { training }\end{array}$ & 8 & 11 & 9 & 11.3 \\
\hline 12 & $\begin{array}{c}\text { Providing specialized } \\
\text { services }\end{array}$ & 10 & 12 & 12 & \\
\hline
\end{tabular}

According to Table 3, the top three OCAs are ensuring product quality, ensuring the quality of raw material, and cost control, which means that quality and cost are two major activities to achieve success for the manufacturers. The next two are development of new product and development of new technology, which means research and development related activities are important to the companies' success. Interestingly, market research and expansion are relatively in the lower level of priority.

\section{Conclusions}

Very few studies in the past have focused on eliciting the OCAs in the manufacturing industry. This study aims to investigate what critical activities are carrying out by the manufacturers in Taiwan. Through the case study approach including the interviews with the senior managers from three manufacturing companies and a series of prioritizing activities, 12 OCAs have been identified. This study also found that Taiwanese manufacturers placed more importance on the activities of quality and cost control while placed relatively less importance on the marketing related activities. Yet, they believed that quality and cost control, manufacturing efficiency, marketing, training, and services are all important to their success. From the government perspective, this study allows the government to better understand the current operation situations of Taiwanese manufacturing industry, and thus to help them develop appropriate policies for them to achieve their success. From the enterprise perspective, the results of this study can provide reference for manufacturers in other countries to elicit their OCAs and to better manage their activities for success. Future research can apply the methods used in this study in other countries or industries for better understanding of achieving organizational success.

\section{References}

1. S. Biazzo, Bus. Process Manage. J, 6, 99-112 (2000)

2. A. Clark, A. Baxter, Manage. Account, 70, 54-55(1992)

3. S. Convey, CMA Magazine, 65, 20-24(1994)

4. W.H. Hung, PhD Thesis(2006)

5. A. Howard, A. Kochhar, J. Dilworth, Int. J. Oper. Prod. Manage, 22, 7-29 (2002)

6. D. Leonard, R. McAdam., J. Eur. Ind. Tr, 26, 4-13(2002) 
7. R.G. Lee, B.G. Dale, Bus. Process Manage. J, 4, 1463-7154(1998)

8. G. Svensson, Manage. Decis, 40, 574-583(2002)

9. J.H. Son, M.H. Kim, J. Syst. Sofwr, 58, 211-219(2001)

10. P.B.B. Turney, Strategic Finance, 73, 20(1994)

11. P.P. Tallon, K.L. Kraemer, Americas Conference on Information Systems (1998).

12. M. Zairi, Bus. Process Manage. J, 3, 64-80(1997) 